\title{
The intersection of integrated pest management and soil quality in the resistant weed era
}

\author{
Audrey V. Gamble, Andrew J. Price \\ Crop, Soil, and Environmental Sciences Department, Auburn University, and National Soil Dynamics \\ Laboratory, USDA Agricultural Research Service, Auburn, AL, USA
}

\begin{abstract}
Highlights
- Conservation tillage hectarage is at constant risk of being converted to higher-intensity tillage systems due to lack of weed control.

- Most tillage operations promote soil loss, adversely affect surface water quality, and negatively impact soil productivity.

- Creative research programs have been developed that meet conservation compliance requirements and, at the same time, judiciously use tillage as an element for the management of resistant or troublesome species.

- Further research is critically needed when few or no other options are available to ensure the economic viability of farming operations while addressing long-term soil quality concerns.
\end{abstract}

\begin{abstract}
Agricultural producers and scientists have long recognized both beneficial and detrimental aspects of soil tillage. With the development and adoption of herbicide-resistant crops, particularly glyphosate-resistant crops, herbicides such as glyphosate replaced the need for tillage either before or after crop planting. Thus, tillage has become less important for weed management and has been a primary enabler for the success of the majority of conservation production systems. Currently, herbicide-resistant and troublesome weeds are continually challenging agricultural decisions throughout the world. Conservation tillage hectarage is at constant risk of being converted to higher-intensity tillage systems due to lack of weed control. The shift to higher-intensity tillage facilitates the burial of weed seed through the use of inversion tillage and/or of surface tillage to facilitate pre-plant incorporated and pre-emergence herbicides for control of herbicide-resistant or troublesome weeds, especially in non-irrigated production. For example, Palmer amaranth (Amaranthus palmeri) has become the
\end{abstract}

Correspondence: Andrew J. Price, Crop, Soil, and Environmental Sciences Department, Auburn University, and National Soil Dynamics Laboratory, USDA Agricultural Research Service, 411 S. Donahue Dr., Auburn, 36832 AL, USA.

E-mail: priceaj@auburn.edu

Key words: Conservation agriculture; herbicide resistance; herbicide trait stewardship.

Received for publication: 16 March 2021.

Revision received: 3 June 2021.

Accepted for publication: 25 June 2021.

CC Copyright: the Author(s), 2021

Licensee PAGEPress, Italy

Italian Journal of Agronomy 2021; 16:1875

doi:10.4081/ija.2021.1875

This article is distributed under the terms of the Creative Commons Attribution Noncommercial License (by-nc 4.0) which permits any noncommercial use, distribution, and reproduction in any medium, provided the original author(s) and source are credited. dominant weed problem in United States row crop production because of evolved resistance to glyphosate. Inversion tillage was clearly demonstrated to be an effective tool in helping the management of this weed. However, there is no question that most tillage operations promote soil loss, adversely affect (lower) surface water quality, and negatively impact soil productivity. Depending on the severity of the herbicide-resistant or troublesome weed infestation, multiple strategies involving the integration of cultural and chemical weed control will be needed to overcome the need for tillage. Utilizing high biomass conservation tillage systems, such as those used extensively in South America and introduced to the United States, can help reduce the emergence of weeds by suppressing weed germination and growth. A dense mat is formed on the soil surface when the winter cover crop is planted early and managed for maximum growth. Because weed emergence and growth are suppressed by the physical barrier and shading provided by the residue, more residue increases weed control. Conservation tillage systems that minimize soil disturbance (direct seeding or minimum tillage) can further reduce weed seed germination. In addition, allelopathy plays a role in weed suppression, but quantifying allelopathic effects in applied research is rarely accomplished. Creative research programs have been developed that meet conservation compliance requirements and, at the same time, judiciously use tillage as an element for the management of resistant or troublesome species. Similar programs are needed to help manage herbicide-resistant or troublesome weed species in other regions and cropping systems. Further research is critically needed when few or no other options are available to ensure the economic viability of farming operations while addressing long-term soil quality concerns.

\section{Introduction}

In the United States (U.S.), conservation agriculture (CA) is defined as a production system that results in at least $30 \%$ of the soil being covered with crop residues after planting. Many systems such as no-till and various reduced tillage practices, including strip-till, mulch-till, and ridge-till, are all considered CA. While early forms of CA (e.g., stubble mulching) were utilized in the U.S. in the 1930s, research on reduced tillage to improve soil quality began in the early 1950s. Early research was focused on 
identifying CA benefits, including reduced soil loss from runoff, reduced labour, and fuel usage, increased soil moisture and organic matter, and improved soil and water quality. As research progressed, the need for practical methods to implement conservation tillage, such as evaluating new equipment, was realized (Gebhardt et al., 1985; Koskinen and McWhorter, 1986; Triplett and Dick, 2008). The introduction of herbicides in the 1960s helped facilitate the producer adoption of CA methods. However, by the early 1980 s, producers identified inadequate weed control as the foremost reason for not adopting CA (Koskinen and McWhorter, 1986).

Marketing of herbicide-resistant crops in some regions in the mid-1990s facilitated the adoption of CA practices with less risk (Green, 2012; Duke, 2015). Over the past 20 years, the adoption of herbicide-resistant crops has been almost universal in some regions. For example, 94\% of all soybeans (Glycine max) planted in the U.S. are herbicide-resistant varieties (USDA, 2015). Corn (Zea mays) and cotton (Gossypium hirsutum) have less area planted solely to herbicide-resistant varieties $(12 \%$ and $10 \%$, respectively) due to the use of stacked gene varieties $(77 \%$ and $79 \%$, respectively). While the adoption of herbicide-resistant crops facilitated an increased adoption of CA, herbicide-resistant weeds pose a growing threat to CA (Price et al., 2011). As a result, producers increasingly face difficult management decisions regarding herbicide-resistant and troublesome weeds.

\section{Conservation agriculture and weed management}

In many regions, typical row crop integrated pest management (IPM) recommendations include tillage practices to disrupt weed life cycles and bury seed at depth beyond germination. Tillage for weed seed bank and emerged weed management are widely used practices and continue to be recommended by cooperative extension and crop consultants as part of IPM strategies throughout the world (Legere et al., 2011; Norsworthy et al., 2012; Shaw et al., 2012; Lyon and Young, 2015). Until the development of highly efficacious herbicides, tillage was required for weed control. With the rapid adoption of herbicide use beginning in the 1960s, tillage combined with herbicide applications provided efficacious control of many troublesome weed species (Timmons, 2005). Combining tillage with herbicides provided control of weeds that were not easily controlled by tillage alone. Historically, herbicide systems have included pre-plant-incorporated (PPI) or pre-emergence (PRE) herbicide applications (or both) to prevent weed germination, followed by post-emergence (POST) or post-directed (PDS) applications to control weeds emerging after the crop throughout the growing season. The herbicide or herbicide program selection is based on several field attributes, including the weed species and their density, an herbicide's efficacy to weed species present, and soil-applied herbicides, soil characteristics, and soil moisture conditions. Weed control practices in cropping systems not utilizing herbicide-tolerant traits require considerable knowledge about herbicide efficacy and weed identification. In addition, substantial labour for scouting and decision-making is required to achieve high efficacy weed control. With the adoption of herbicide-resistant crops (i.e., predominantly glyphosate-resistant crops since most corn, cotton, and soybean marketed in North and South America contain this trait), herbicides have replaced the need for tillage either before and/or after crop planting. Tillage has become less important for weed management; thus herbicide-resistant crop adoption has been a primary reason for the increase in CA hec- tarage (Shaw et al., 2012). However, because of extraordinary herbicide selection pressure, resistant weeds are now present throughout the U.S. Currently, there are 153 herbicide-resistant weeds in the U.S. (Heap, 2015). Despite many hectares with herbicide-resistant weeds currently being CA systems, the difficulty of controlling these herbicide-resistant weeds places many of them at risk of being converted to higher-intensity tillage systems (Price et al., 2011). The shift to higher-intensity tillage facilitates the burial of small weed seed and/or increased pre-plant incorporated herbicide activity to control problematic weeds, especially in dry-land crop production, such as cotton.

\section{Soil tillage and soil quality}

Soils hold approximately $1500 \mathrm{Pg} \mathrm{C}$, making them the largest component of the global terrestrial C stock (Scharlemann et al., 2014). Globally, agricultural soils have lost 36 to $78 \%$ of their initial soil organic carbon (SOC) in the top $30 \mathrm{~cm}$ of soil, largely due to frequent and disruptive tillage (Trimble, 1974; Sanderman et al., 2018). Disturbance of soil aggregates and aeration of soil are maximized with conventional tillage, increasing microbial activity and subsequent release of $\mathrm{CO}_{2}$ to the atmosphere (Sainju et al., 2010). The use of CA practices, including reduced tillage, has been used to rebuild SOC, and it has been estimated that shifting from conventional tillage to conservation tillage can result in $\mathrm{C}$ sequestration rates of 0.45 to $1 \mathrm{Mg} \mathrm{C} \mathrm{ha}^{-1} \mathrm{yr}^{-1}$ dependent on soil type and climate (Franzluebbers, 2010; Zomer et al. 2017). Thus, conservation agriculture practices are critical to meet global initiatives to mitigate climate change like the 4 per mille Soils for Food Security and Climate program (Budiman et al., 2017). In addition to $\mathrm{C}$ sequestration, the benefits of CA practices to build SOC are widespread. Soil organic $\mathrm{C}$ is a universally accepted indicator of soil health because of its role in increasing soil nutrient-holding capacities, supporting microbial communities, improving soil aggregation and structure, and enhancing water infiltration and storage (Touchton et al., 1984; Franzluebbers and Stuedmann, 2008; Watts et al., 2010; Hawkins et al., 2016; Nunes et al., 2020).

As herbicide-resistant weeds become an increasingly prevalent issue globally, it is imperative to identify control methods that do not damage the advancements which have been made in protecting soil health. Reversion to conventional tillage systems threatens carbon sequestration made in recent decades. Increased $\mathrm{C}$ losses of 0.5 to $1.8 \mathrm{Mg} \mathrm{C}$ ha $^{-1} \mathrm{yr}^{-1}$ measured as $\mathrm{CO}_{2}$ emissions have been reported for conventional tillage methods (e.g., mouldboard plow, chisel plow) compared to no-tillage (Omonode et al., 2007; Ussiri and Lal, 2009; Heller et al., 2010). Losses of approximately $770 \mathrm{~kg}$ $\mathrm{C} \mathrm{ha} \mathrm{yr}^{-1} \mathrm{yr}^{-1}$ were reported in sandy loam soils under conventional tillage in Italy using simulation models (Cillis et al., 2018). Losses of SOC also threaten to reverse associated improvements in soil fertility, soil structure, and soil biology. High-residue cover crops will be an integral part of herbicide-resistant weed management to shade the soil surface to prevent weed germination and compete with weed species for water and nutrient resources. Approximately $64 \%$ of farmers $(n=869)$ reported that herbicide-resistant weeds are an issue on their farms in a recent survey of U.S. farmers (CTIC, $2020)$. In the same survey, $91.2 \%$ of farmers $(n=317)$ reported an improvement in weed control with a high-residue rye cover crop. A large barrier to the production of high residue $(>4000 \mathrm{~kg}$ biomass $\mathrm{ha}^{-1}$ ) cover crop is timely planting since ideal planting windows for many wintry annual cover crops often occur before the harvest of cash crops. Innovative planting methods (e.g., inter- 
seeding, aerial broadcasting) and variety selection for earliermaturing winter annual cover crops may create conditions in which high biomass production is more feasible. In the case of interseeding cover crops, additional research is needed to identify

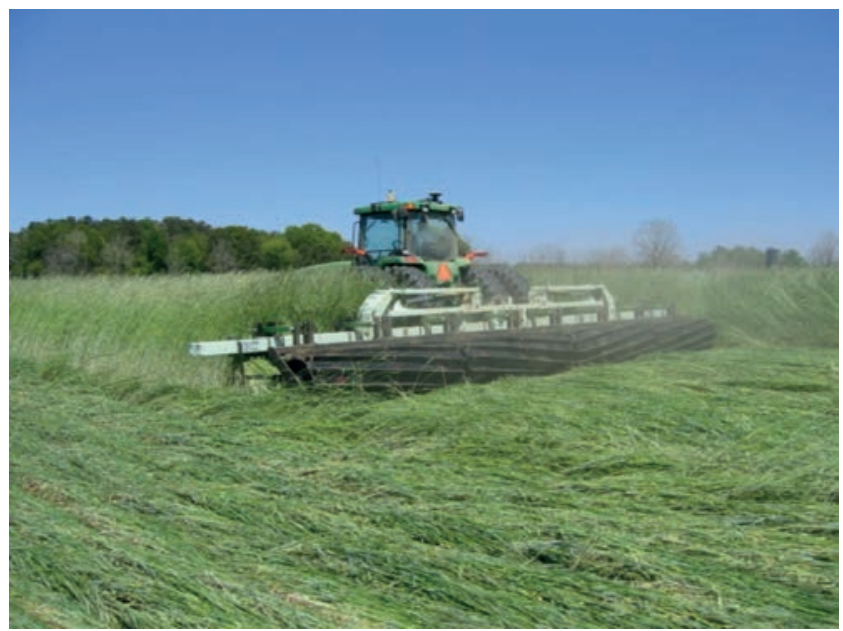

Figure 1. Cover crop roller/crimper terminating a cereal rye cover crop.

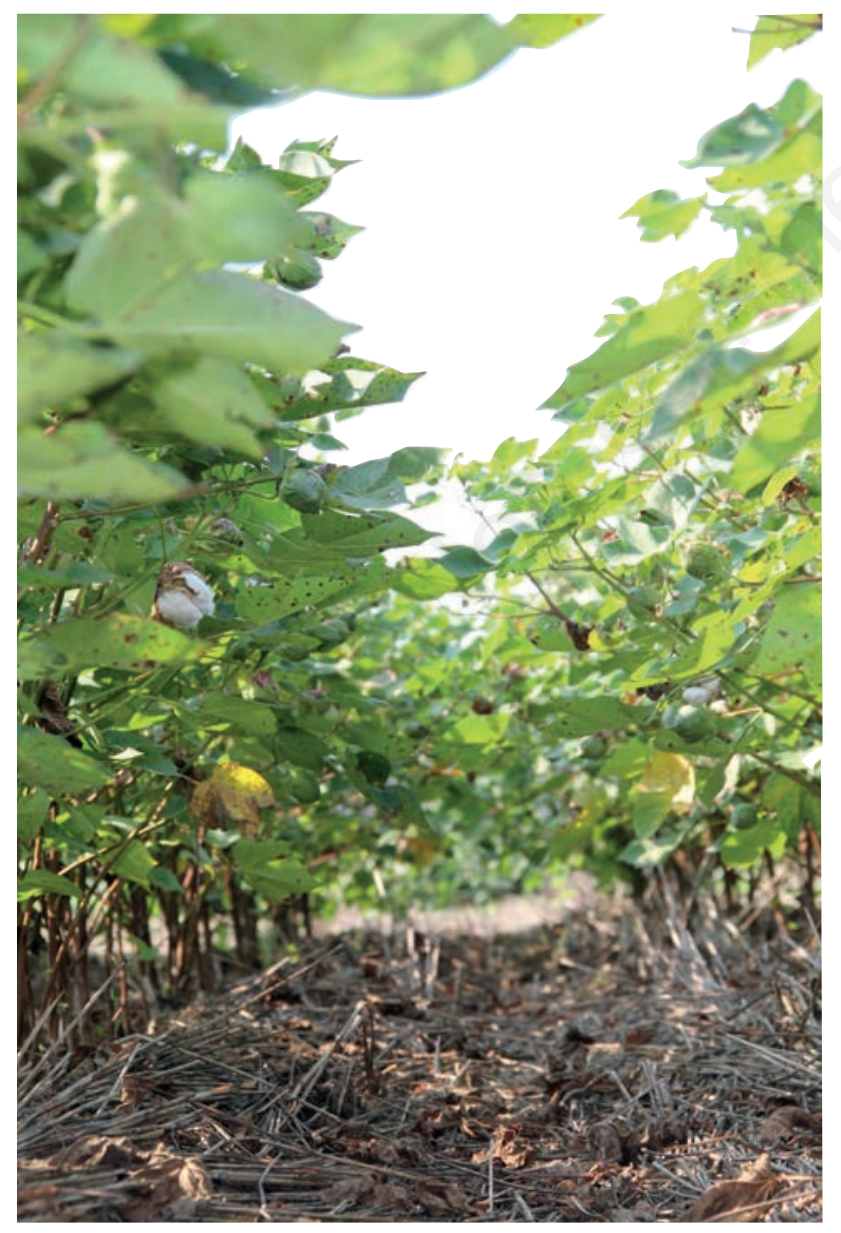

Figure 2. Cotton grown in rolled high-biomass cereal rye cover crop residue. species that provide adequate ground coverage without competing with the cash crop. Planting summer annual cover crops may also be useful for crop rotations in which early harvest leaves soil exposed prior to winter cover crop planting.

\section{Integrated pest management weed management practices to maintain conservation agriculture}

The renewed interest in both high biomass winter and summer annual cover crops and their management for both soil quality and weed control attributes (Balkcom et al., 2013). In the late-1990s, scientists at Auburn University and USDA - ARS National Soil Dynamics Laboratory, both in Auburn, Alabama, initiated research using a cover crop roller-crimper, a Brazilian style CA cover crop management practice used in combination with herbicides to terminate mature cover crops (Derpsch et al., 1991; Ashford and Reeves, 2003; Price et al., 2009; Balkcom et al., 2015) (Figure 1). This practice was initially evaluated in CA cereal cover crops preceding cotton (Figure 2), soybean, and peanut. In the U.S., rollercrimpers have since been successfully used in CA systems to terminate a broad range of cover crops practices, including traditional and alternative species, grasses and broadleaves, summer and winter, and monocultures and mixtures (Price et al., 2006; Kornecki and Arriaga, 2011; Reberg-Horton et al., 2011; Price et al., 2012). High-biomass cover crops contribute advantages of CA systems by promoting moisture conservation after cover crop termination, as well as weed suppression (Teasdale, 1996; Arriaga and Balkcom, 2006). In addition, high-residue cover crops are increasingly being recommended as an IPM practice to help alleviate herbicide resistance selection pressure through their suppressive weed characteristics (Norsworthy et al., 2012). Another renewed cover crop management interest is mixing different cover crop species to increase the biological diversity of CA systems. Little research has been published in this area; however seed companies and technology transfer specialists in extension and farming associations tout advantages provided by cover crop mixtures, including soil health benefits (USDA, 2012; Solberg, 2013; White et al., 2015).

\section{Conclusions}

Creative research programs have been developed that meet conservation compliance requirements and, at the same time, judiciously use tillage as an element for the management of resistant or troublesome species. Similar programs are needed to help manage other herbicide-resistant or troublesome weed species in other regions and cropping systems. Impacts on soil health should be considered when developing programs for managing the resistant weeds, and further research is critically needed when few or no other options are available to ensure the economic viability of farming operations while addressing long-term soil quality concerns.

\section{References}

Arriaga FJ, Balkcom KS, 2006. Benefits of conservation tillage on rainfall and water management. In: K.J. Hatcher (Ed.), Proceedings of the 2005 Georgia Water Resources Conference, 
April 25-27, 2005.

Ashford DL, Reeves DW, 2003. Use of a mechanical rollercrimper as an alternative kill method for cover crops. Am. J. Altern. Agric. 18:37-45.

Balkcom KS, Arriaga FJ, van Santen E, 2013. Conservation systems to enhance soil carbon sequestration in the Southeast U.S. Coastal Plain. Soil Sci. Soc. Am. J. 77:1774-83.

Balkcom KS, Duzy LM, Kornecki TS, Price AJ, 2015. Termination of cover crops in the southeast: management considerations for the subsequent cash crop. Crop Forage Turf. Manage. 1:1-7.

Budiman M, Malone BP, McBratney AB, Angers DA, Arrouays D, Chambers A, Chaplot V, Chen Z, Cheng K, Das BS, Field DJ, Gimona A, Hedley CB, Hong SY, Mandal B, Marchant BP, Martin M, McConkey BG, Mulder VL, O'Rourke S, Richerde-Forges AC, Odeh I, Padarian J, Paustian K, Pan G, Poggio L, Savin I, Stolbovoy V, Stockmann U, Sulaeman Y, Tsui C, Vågen T, van Wesemael B, Winowiecki L, 2017. Soil carbon 4 per mille. Geoderma 292:59-86.

Cillis D, Maestrini B, Pezzuolo A, Marinello F, Sartori L, 2018. Modelling soil organic carbon and carbon dioxide emissions in different tillage systems supported by precision agriculture technologies under current climatic conditions. Soil Till. Res. 183:51-9.

CTIC, 2020. Report of the 2019-20 National Cover Crop Survey. Joint publication of the Conservation Technology Information Center, the North Central Region Sustainable Agriculture Research and Education Program, and the American Seed Trade Association, West Lafayette, IN, USA. Available from: https://www.ctic.org/data/Cover_Crops_Research_and_Demo nstration_Cover_Crop_Survey\#: : text=2019\%2D2020\%20Co ver $\% 20$ Crop $\% 20$ Survey\&text=Among $\% 20$ farmers $\% 20$ who $\%$ 20 planted $\% 20$ green,and $\% 202.6 \% 25 \% 20$ in $\% 20$ spring $\% 20$ wh eat.

Derpsch R, Roth CH, Sidiras N, Ko"pke U. 1991. Controle da erosa o no Parana', Brazil: Sistemas de cobertura do solo, plantio directo e prepare conservacionista do solo. Deutsche Gesellschaft fü r Technische Zusammenarbeit (GTZ) GmbH, Eschborn, Germany.

Duke SO, 2015. Perspectives on transgenic, herbicide-resistant crops in the United States almost 20 years after introduction. Pest Manage. Sci. 71:652-57.

Franzluebbers AJ, 2010. Achieving soil organic carbon sequestration with conservation agricultural systems in the southeastern United States. Soil Sci. Soc. Am. J. 74:347-57.

Franzluebbers AJ, Stuedemann JA, 2008. Early response of soil organic fractions to tillage and integrated crop-livestock production. Soil Sci. Soc. Am. J. 72:613-25.

Gebhardt MR, Daniel TC, Schweizer EE, Allmaras RR, 1985. Conservation tillage. Science 230:625-30.

Green JM, 2012. The benefits of herbicide-resistant crops. Pest Manage. Sci. 68:1323-31.

Hawkins GL, Kelton J, Smith N, Balkcom K, 2016. A note on comparing rate of soil moisture loss for conventional and conservation tillage production methods for peanut. Peanut Sci. 43:168-72.

Heller H, Bar-Tal A, Tamir G, Bloom P, Venterea RT, Chen D, Zhang Y, Clapp CE, Fine P, 2010. Effects of manure and cultivation on carbon dioxide and nitrous oxide emissions from a corn field under Mediterranean conditions. J. Environ. Qual. 39:437-48.

Heap I, 2015. The international survey of herbicide resistant weeds. Available from: http://www.weedscience.org Accessed: November 2015.
Kornecki TS, Arriaga FJ, 2011. Impact of different cover crops and types of transplanter mounted subsoiler shanks on tomato yield. HortSci. 46:715-20.

Koskinen WC, McWhorter CG, 1986. Weed control in conservation tillage. J. Soil Water Conserv. 41:365-70.

Legere A, Stevenson FC, Benoit DL, 2011. The selective memory of weed seedbanks after 18 years of conservation tillage. Weed Sci. 59:98-106.

Lyon DJ, Young FL, 2015. Integration of weed management and tillage practices in spring barley production. Weed Technol. 29:367-73.

Norsworthy JK, Ward SM, Shaw DR, Llewellyn RS, Nichols RL, Webster TM, Bradley KW, Frisvold G, Powles SB, Burgos NR, Witt WW, Barrett M, 2012. Reducing the risks of herbicide resistance: Best management practices and recommendations. Weed Sci. 60:31-62.

Nunes MR, Karlen DL, Veum KS, Moorman TB, Cambardella CA, 2020. Biological soil health indicators respond to tillage intensity: A US meta-analysis. Geoderma 369:114335.

Omonode RA, Vyn TJ, Smith DR, Hegymegi P, Gál A, 2007. Soil carbon dioxide and methane fluxes from long-term tillage systems in continuous corn and corn-soybean rotations. Soil Till. Res. 95:182-95.

Price AJ, Arriaga FJ, Raper RL, Balkcom KS, Kornecki TS, and Reeves DW, 2009. Comparison of mechanical and chemical winter cereal cover crop termination systems and cotton yield in conservation agriculture. Cotton Sci. 13:238-45.

Price AJ, Balkcom KS, Culpepper SA, Kelton JA, Nichols RL, Schomberg H, 2011. Glyphosate-resistant Palmer amaranth: A threat to conservation agriculture. J. Soil Water Conserv. 66:265-75.

Price AJ, Balkcom KS, Duzy LM, Kelton JA, 2012. Herbicide and cover cop residue integration for Amaranth control in conservation agriculture cotton. Weed Technol. 26:490-8.

Price AJ, Reeves DW, Patterson MG, 2006. Evaluation of weed control provided by three winter cereals in conservation-tillage soybean. Renew. Agric. Food Syst. 21:159-64.

Reberg-Horton SC, Grossman JM, Kornecki TS, Meijer AD, Price AJ, Place GT, Webster TM, 2011. Utilizing cover crop mulches to reduce tillage in organic systems in the Southeast. Renew. Agric. Food Syst. 27:41-8.

Sanderman J, Hengl T, Fiske GJ, 2017. Soil carbon debt of 12,000 years of human land use. Proc. Natl. Acad. Sci. U. S. A. 114:9575-80.

Scharlemann JP, Tanner EV, Hiederer R, Kapos V, 2014. Global soil carbon: understanding and managing the largest terrestrial carbon pool. Carbon Manage. 5:81-91.

Shaw D, Culpepper SA, Owen M, Price AJ, Wilson R, 2012. Herbicide-resistant weeds threaten soil conservation gains: finding a balance for soil and farm sustainability. Issue Paper 49. CAST, Ames, Iowa, USA.

Solberg K, 2013. Cover crop fact sheet. Available from: http://www.sfa-mn.org/wp-content/uploads/2013/04/CoverCrop-Fact-Sheet.pdf Accessed: October 2015.

Teasdale JR, 1996. Contribution of cover crops to weed management in sustainable agricultural systems. J. Prod. Agric. 9:475-9.

Timmons FL, 2005. A history of weed control in the US and Canada. Weed Sci. 53:748-61.

Touchton JT, Rickerl DH, Walker RH, Snipes CE, 1984. Winter legumes as a nitrogen source for no-tillage cotton. Soil Till. Res. 4:391-401.

Trimble SW, 1974. Man-induced soil erosion on the southern piedmont: 1700-1970. Soil Conservation Society of America, 
Ankeny, IA, USA.

Triplett Jr GB, Dick WA, 2008. No-tillage crop production: A revolution in agriculture! Agron. J. 100:S-153-S-165.

USDA, 2012. Unlock your farm's potential: Discover the cover. Natural Resources Conservation Service. Available from: http://www.nrcs.usda.gov/Internet/FSE_DOCUMENTS/stelprdb1049063.pdf Accessed: October 2015.

USDA, 2015. Adoption of genetically engineered crops in the U.S. Economic Research Service. Available from: http://www.ers.usda.gov/data-products/adoption-of-genetically-engineered-crops-in-the-us.aspx Accessed: 11 November 2015.

Ussiri DAN, Lal R, 2009. Long-term tillage effects on soil carbon storage and carbon dioxide emissions in continuous corn crop- ping system from an alfisol in Ohio. Soil Till. Res. 104:39-47.

Watts DB, Torbert HA, Prior SA, Huluka G, 2010. Long-term tillage and poultry litter impacts soil carbon and nitrogen mineralization and fertility. Soil Sci. Soc. Am. J. 74:1239-47.

White C, Barbercheck M, Dupont T, Finney D, Hamilton A, Hartman D, Hautau M, Hinds J, Hunter M, Kaye J, La Chance J, 2015. Making the most of mixtures: considerations for winter cover crops in temperate climates. Available from: http://articles.extension.org/pages/72973/making-the-most-ofmixtures:-considerations-for-winter-cover-crops-in-temperateclimates\#.VkP-m41dEqO Accessed: October 2015.

Zomer RJ, Bossio DA, Sommer R, Verchot LV, 2017. Global sequestration potential of increased organic carbon in cropland soils. Sci. Reports 7:15554. 